DR. THOMAS SYDENHAM (1624-1689) 
Other studies in medical history by the same author

The Quicksilver Doctor: The Life and Times of Thomas Dover, Physician and Adventurer, John Wright and Sons, Ltd., Bristol, I957.

John Locke (1632-1704), Physician and Philosopher: $A$ Medical Biography with an Edition of the Medical Notes in his Joumals, Wellcome Historical Medical Library, London, 1963. 



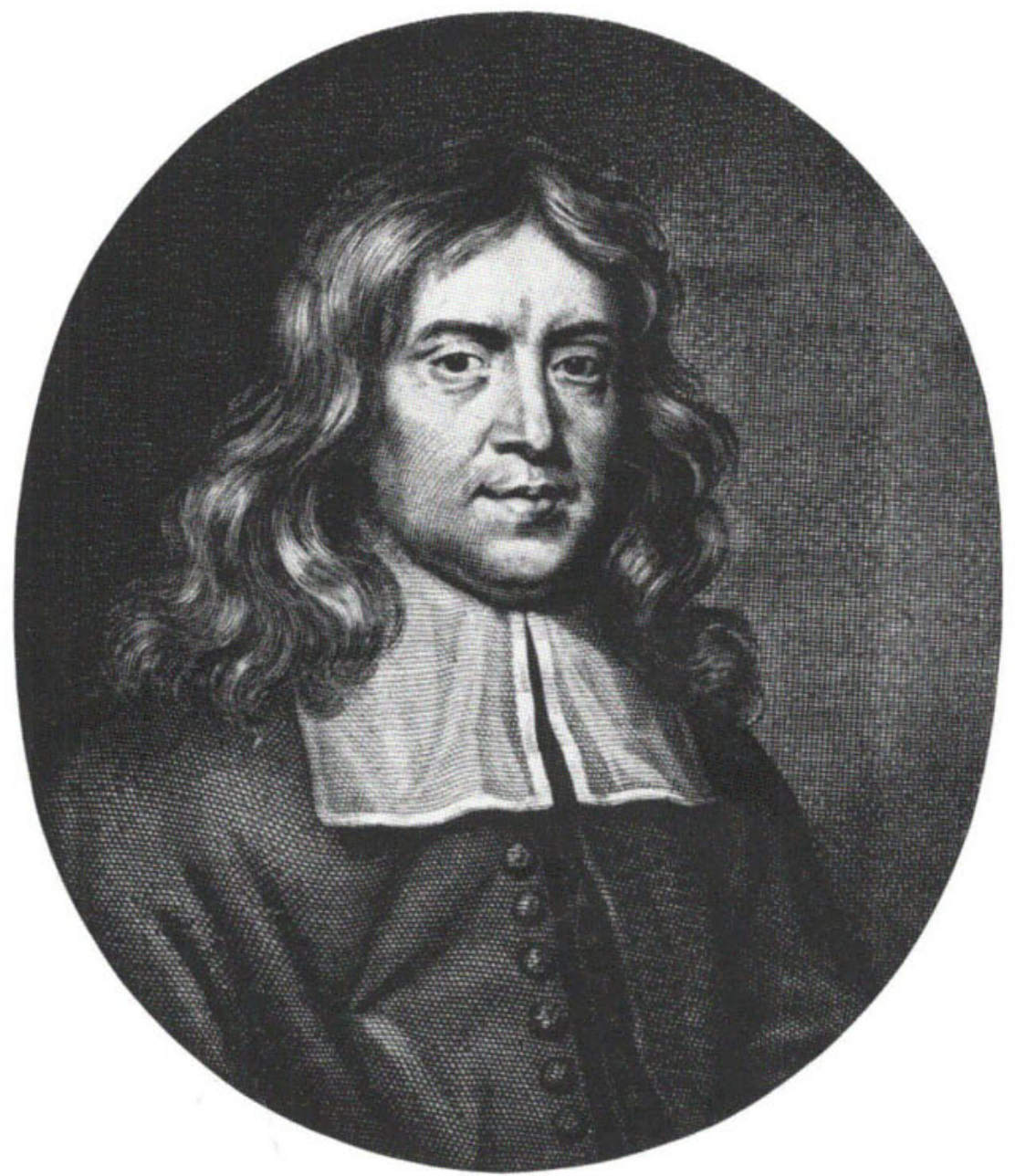

An cngraving of Mary Beale's portrait of Thomas Sydenham, reproduced from the first edition of his Observationes . Medicac, etc. (1676). 


\section{KENNETH DEWHURST}

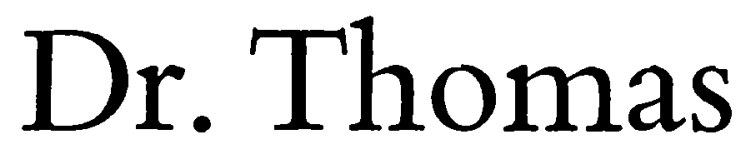

Sydenham

(I624-I689)

His Life and

Original Writings

UNIVERSITY OF CALIFORNIA PRESS

BERKELEY AND LOS ANGELES

I 966 


\section{PUBLISHED IN THE UNITED STATES OF AMERICA \\ BY THE UNIVERSITY OP CALIFORNIA PRESS \\ BERXELBY AND LOS ANGELES, CALIFORNIA}

LIBRARY OP CONGRESS CATALOG CARD NUMBER: 66-19348

THIS WORK IS ALSO PUBLISHED IN THE UNITED KINGDOM BY THE WELLCOME HISTORICAL MEDICAL LIBRARY, LONDON

(C) Kenneth Dewhurst 1966

All Rights Reserved 